\begin{tabular}{|c|c|c|c|}
\hline $\begin{array}{l}\text { Case } \\
\text { No }\end{array}$ & $\begin{array}{c}\text { Age } \\
\text { at death } \\
\text { (years) }\end{array}$ & $\begin{array}{l}\text { Main cause of death } \\
\text { (as stated on death certificate) }\end{array}$ & Clinical details \\
\hline 1 & 9 & $\begin{array}{l}\text { (a) Bronchopneumonia } \\
\text { (b) Chronic respiratory failure } \\
\text { (c) Asthma }\end{array}$ & $\begin{array}{l}\text { Severe mental retardation; resident of long stay mental hospital. Acute asthmatic episode one } \\
\text { month before death }\end{array}$ \\
\hline 2 & 10 & Status asthmaticus & $\begin{array}{l}\text { Mental and physical retardation. Known to be asthmatic. Dose of inhaled steroids reduced two } \\
\text { weeks before death }\end{array}$ \\
\hline 3 & 14 & Status asthmaticus & Developmental delay. Known to be asthmatic \\
\hline 4 & 22 & Status asthmaticus & $\begin{array}{l}\text { Severe subnormality with aggressive behaviour; resident of long stay mental hospital. Asthma not } \\
\text { recognised before terminal illness }\end{array}$ \\
\hline 5 & 22 & Status asthmaticus & Delayed physical and mental development. Known to be asthmatic; taking oral and inhaled steroids \\
\hline 6 & 36 & $\begin{array}{l}\text { (a) Congestive cardiac failure } \\
\text { (b) Cor pulmonale } \\
\text { (c) Asthma and emphysema }\end{array}$ & $\begin{array}{l}\text { Prader-Willi syndrome; resident of long stay mental hospital. Acute asthmatic episode one month } \\
\text { before death }\end{array}$ \\
\hline 7 & 37 & Status asthmaticus & $\begin{array}{l}\text { Mental retardation; resident of long stay mental hospital. Recommended maintenance treatment } \\
\text { with steroids not implemented }\end{array}$ \\
\hline 8 & 42 & $\begin{array}{l}\text { (a) Acute respiratory failure } \\
\text { (b) Bronchial asthma }\end{array}$ & "Dull normal" with IQ of 85. Known to be asthmatic. Treatment at time of death not known \\
\hline
\end{tabular}

the severity of an asthmatic attack. There may also be delays on the part of nursing and medical staff in recognising or responding to an attack. Such factors have been shown to contribute to deaths from asthma in the general population. ${ }^{2}$ We suggest that giving attention to the management of asthma in both adults and children with learning difficulties may be important in preventing death from this cause.

We thank Dr Mary McGraw for help in reviewing the records of deaths in children.
1 Charlton J, Lakhani A. Avoidable deaths study 1974-83. Inter-authority comparisons and consultancy. Birmingham: Health Services Management Centre, 1986.

2 British Thoracic Association. Deaths from asthma in two regions of England. BrMed f 1982;285:1251-5.

3 Yates J. Inter-authority comparisons 1986. Birmingham: Health Services Management Centre, 1987

4 Johnson KW. Mortality for conditions amenable to medical intervention in Walsall and other health authorities in the Wet Midlands region. Birmingham: West Midlands Health Authority, 1986.

5 Pledger HG, Fahy LT, van Mourik GA, Bush GH. Deaths in children with a diagnosis of acute appendicitis in England and Wales 1980-4. Br Med $\mathcal{J}$ 1987;295:1233-5.

(Accepted 27 December 1989)
Leiden University,

The Netherlands

B R Bloem, medical student

University Hospital, PO Box 9600, 2300 RC, Leiden, The Netherlands A M Lagaay, $\mathrm{MD}$, research fellow, gerontology section, department of pathology

W van Beek, MD, research fellow, gerontology section, department of pathology

$\mathrm{J}$ Haan, MD, lecturer, department of neurology R A C Roos, MD, senior lecturer, department of neurology

A R Wintzen, MD, senior lecturer, department of neurology

Correspondence to:

Dr Wintzen.

$\operatorname{BrMed} \mathcal{F} 1990 ; 300: 721-2$

\section{Prevalence of subjective dysphagia in community residents aged over 87}

\section{B R Bloem, A M Lagaay, W van Beek, J Haan, R A C Roos, A R Wintzen}

Dysphagia may have many implications for social and physical health; dysphagic people often have malnutrition and airway infections due to aspiration, and their reluctance to eat meals with others present may lead to social isolation. The prevalence of dysphagia increases with age, ${ }^{+}$but there have been no studies of dysphagia in unselected elderly people. We therefore studied the prevalence of subjective dysphagia in a population of elderly people living in the community.

\section{Subjects, methods, and results}

In a gerontological study in Leiden, of the total cohort of 1259 residents aged 85 years or over on the

Occurrence of dysphagia by sex, age, mini mental state examination score, and coexistence of diseases. Unless stated otherwise figures are numbers of subjects

\begin{tabular}{|c|c|c|c|c|}
\hline & \multirow[b]{2}{*}{ Total } & \multicolumn{2}{|c|}{ Dysphagic } & \multirow{2}{*}{$\begin{array}{c}\text { Odds ratio } \\
\text { (95\% confidence interval) } \\
\text { and significance }\end{array}$} \\
\hline & & Yes & No & \\
\hline Total & 130 & 21 & 109 & \\
\hline \multicolumn{5}{|l|}{ Sex: } \\
\hline Men & 27 & 3 & 24 & NS \\
\hline \multirow{2}{*}{\multicolumn{5}{|c|}{ Age (years): }} \\
\hline & & & & \\
\hline $87-89$ & 73 & 10 & 63 & NS \\
\hline $90-95$ & 57 & 11 & 46 & NS \\
\hline \multirow{2}{*}{\multicolumn{5}{|c|}{ Mini mental state examination score ${ }^{\star}$ : }} \\
\hline & & & & \\
\hline$\geqslant 24$ & 90 & 13 & 77 & NS \\
\hline $17-24$ & 27 & 6 & 21 & NS \\
\hline$\leqslant 17$ & 12 & 1 & 11 & NS \\
\hline Mean & $25 \cdot 0(5 \cdot 0)$ & $24 \cdot 9(4 \cdot 1)$ & $25 \cdot 0(5 \cdot 2)$ & NS \\
\hline Stroke and Parkinson's disease & 19 & 9 & 10 & $7.43(2.52 \text { to } 21.9)^{\star \star}$ \\
\hline Oesophageal stenosis & 3 & 2 & 1 & $11.37(0.98 \text { to } 131 \cdot 7)^{\star \star \star}$ \\
\hline
\end{tabular}

entry date of 31 December 1985, 977 were visited at home. They all had a medical interview and the mini mental state examination. ${ }^{2}$ In August 1988 a questionnaire about symptoms on swallowing or choking, or both, was added and included the following questions: Are you bothered either by choking or coughing after eating or drinking, or by pieces of food getting stuck in the throat, or swallowing more than once to get the same bite down, or spilling swallowed fluid through the nose?

Out of the 977 subjects, data on swallowing were available from 136. Because people living in nursing homes had been visited early in the study the subgroup visited after August 1988 consisted of subjects living at home. People who gave a positive answer to one or more questions were considered to be dysphagic. Incomplete medical interviews were excluded from the analysis. The results were analysed statistically by $\chi^{2}$ and Kendall's Tau B tests.

Six subjects were unable to complete the interview, which left 130 for analysis. Twenty one subjects (16\%) gave a positive answer to one or more questions. Dysphagia was not related to age, sex, or mini mental state score ( $p>0 \cdot 10$; table). Disorders of the central nervous system (Parkinson's disease and stroke) or oesophageal stenosis confirmed by a doctor occurred significantly more commonly in dysphagic than nondysphagic subjects.

In six subjects the dysphagia was particularly severe: four reported daily choking, or impaired passage of food, or both, two of whom had to be extremely careful with every meal. The two remaining subjects had been forced by dysphagia to restrict their diet to porridge. Strikingly, none of these six subjects had volunteered symptoms before.

\section{Comment}

The number of subjects who gave a positive answer to one or more questions indicates that dysphagia is common in people aged over 87 . Reports on the impact of dysphagia on populations of older people are scarce. 
This may partly be explained by the fact that even severely dysphagic people do not always volunteer symptoms, as shown by the six subjects in our study who had never consulted a doctor for their daily discomfort during meals. The tendency for elderly people to accept their problems as an inevitable manifestation of old age is probably the cause of this failure to seek help, ${ }^{3}$ resulting in underreporting of symptoms so that the actual prevalence of dysphagia may be even higher than our findings suggest. Moreover, by selecting subjects living in the community we may have excluded less healthy people, thus further underestimating the prevalence of dysphagia.

The relative extent to which dysphagia is caused by either aging or specific diseases is unknown. Our findings show a high correlation between dysphagia

and diseases of the central nervous system and oesophagus. The cause of dysphagia in people not reporting specific diseases, however, remains uncertain, so aging as a cause of senile dysphagia cannot be excluded.

This study was part of a project financed by National Institutes of Health grant 5 ROl AG06354 A M Lagaay and W van Beek). We thank W Hijmans for advice and $\mathrm{E} A$ van der Velde for the statistical analysis.

1 Borgstrom PS, Ekberg O. Pharyngeal dysfunction in the elderly. Fournal of Medical Imaging 1988;2:74-81

2 Folstein MF, Folstein SE, McHugh PR. "Mini-mental state": a practical method for grading the cognitive state of patients for the clinician. I lswchiutr $^{\text {s. }}$ $R \backsim 1975: 12: 189-98$

3 Rowe JW. Health care of the elderly. N Engl F Med 1985;312:827-35.

(Accepted 21 December 1989)

\section{Use of skin thermometer to diagnose acute appendicitis}

\section{J E Hambidge}

Princess Alexandra's Hospital, Wroughton, Wiltshire SN4 0QJ $\mathrm{J}$ E Hambidge, FRCंSED, registrar in surgery

Correspondence to: Mr J E Hambidge, Princess Mary's Royal Air Force Hospital, Halton, Aylesbury,

Buckinghamshire HP22 5PS.

$\operatorname{BrMed~f~1990;300:722~}$
Diagnosing appendicitis before operation is often difficult, especially in children.' Thus $15-20 \%$ of appendicectomies are unnecessary on clinical grounds alone. ${ }^{2}$ Various tests have been suggested to increase the accuracy of diagnosis, including the white cell count and thermography. The white cell count is insensitive, but its sensitivity can be improved by combining it with estimations of $\mathrm{C}$ reactive protein concentration and erythrocyte sedimentation rate. ${ }^{3}$ Steele found that thermography had no value as a diagnostic technique, ${ }^{+}$although a Russian study showed that local skin temperature in the right iliac fossa may be a useful indicator. ${ }^{5}$ I studied the accuracy of using a thermometer that is usually used on children's foreheads (Feverscan; Robinsons of Chesterfield) in diagnosing appendicitis.

\section{Patients, methods, and results}

The thermometer measures skin temperature to the nearest degree Celsius and has a range from $35-40^{\circ} \mathrm{C}$. A reading is taken after it has been held to the skin for 15 seconds. Twenty five consecutive patients who had already been selected for appendicectomy by routine clinical assessment had their skin temperature measured before the operation. The temperature was measured over McBurney's point and a corresponding position on the left. Patients were considered to have acute appendicitis if the skin temperature on the right was at least $1^{\circ} \mathrm{C}$ warmer than that on the left. Surgical findings and histological results were noted. Twenty five consecutive patients admitted for planned orthopaedic procedures (controls) were similarly assessed.

The table shows the results. Negative results were obtained for all the controls, and all the patients in whom the response was positive had appendicitis. Some false negative results occurred.
Results of using Feverscan thermometer to diagnose appendicitis

\begin{tabular}{lccc}
\hline & $\begin{array}{c}\text { No of positive } \\
\text { results }\end{array}$ & $\begin{array}{c}\text { No of negative } \\
\text { results }\end{array}$ & Total \\
\hline Patients: & & 8 & \\
$\quad$ With appendicitis & 14 & 3 & 22 \\
$\quad$ Without appendicitis & & 25 & 25 \\
Controls & & 36 & 50 \\
\hline Total & 14 & 36 \\
\hline
\end{tabular}

^Appendicitis confirmed by histological examination after operation.

\section{Comment}

These results show that the test has a sensitivity of $64 \%$, a specificity of $100 \%$, a positive predictive value of $100 \%$, a negative predictive value of $27 \%$, and an overall accuracy of $68 \%$. If the negative results from the control group are included the negative predictive value is increased to $78 \%$ and the accuracy to $84 \%$. Although a negative result did not exclude appendicitis, a positive result always indicated it.

The Feverscan thermometer is accurate only to the nearest degree Celsius. Other, more accurate methods of assessing skin temperature are available, but they do not have the benefits of being easy to use, portable, and inexpensive.

Thermography has been reported in one study to be of little use in diagnosing appendicitis. ${ }^{4} \mathrm{My}$ results, on the other hand, support those of a Russian study that showed the technique to be of value. I now intend to carry out a larger study, using the Feverscan thermometer to assess all patients presenting with acute abdominal pain.

\section{O'Shea JS, Bishop ME, Alario AJ, Cooper JM. Diagnosing appendicitis in children with acute abdominal pain. Pediatr Emerg Care 1988;4:172-6. \\ 2 Blind PJ, Dahlgren ST. The continuing challenge of the negative appendix. Acta Chir Scand 1986:152:623-7. \\ 3 Marchand A Van Lente F. Galen RS. The assessment of laboratory tests in the diagnosis of acute appendicitis. Am 7 Clin Pathol 1983;80:369-74. \\ 4 Steele RJ. Abdominal thermography in acute appendicitis. Scott Med $\mathscr{f}$ 1986;31:299-30 \\ 5 Zakharov SN, Svitich IM, Baskakov VA. Electrothermometry in the diagnosi of destructive forms of acute appendicitis and acute cholecystitis. Khirurgiic (Sofiia) 1981;10:37-9.}

(Accepted 1 December 1989)

\section{ONE HUNDRED YEARS AGO}

On his arrival at Alexandria on January 22nd, Surgeon Parke was welcomed by Brigade-Surgeon Gore, Senior Medical Officer of the Alexandria garrison. Surgeon Parke was serving at Alexandria up to February 2nd, 1887, when he started to join Stanley, and was, therefore, among old friends on returning to that city last month; by them he was entertained at a dinner over which Sir Charles A. Cookson, K.C.M.G., C.B., presided. Speaking in response to the toast of his health, Surgeon Parke gave a short account of the difficulties which the expedition had encountered, and spoke in warm terms of the energy and determination of its leader. Referring to the health of the expeditionary force, he said that the experience it had afforded appeared to prove that the white man had a better chance than the black man of living in Africa, for out of eleven white men only one life was lost, while considerably more than half the blacks perished. Dr. Parke considered it augured well for the future of Africa that it was proved that it could be colonised by white men. (British Medical Fournal 1890;i:310.) 